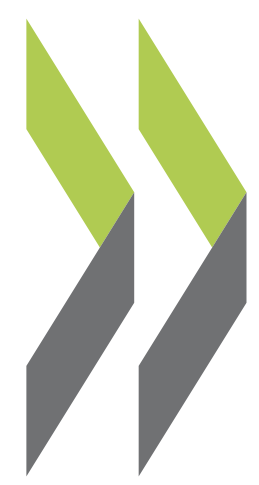

OECD Science, Technology and Industry Working Papers $2002 / 12$

Use of Plant-Level MicroData for the Evaluation of SME Innovation Policy Kazuyuki Motohashi in Japan 
Organisation de Coopération et de Développement Economiques

DIRECTORATE FOR SCIENCE, TECHNOLOGY AND INDUSTRY

STI WORKING PAPERS 2002/12

USE OF PLANT-LEVEL MICRO-DATA FOR THE EVALUATION OF SME INNOVATION POLICY IN JAPAN

Kazuyuki Motohashi 


\section{STI Working Paper Series}

The Working Paper series of the OECD Directorate for Science, Technology and Industry is designed to make available to a wider readership selected studies prepared by staff in the Directorate or by outside consultants working on OECD projects. The papers included in the series cover a broad range of issues, of both a technical and policy-analytical nature, in the areas of work of the DSTI. The Working Papers are generally available only in their original language - English or French - with a summary in the other.

Comment on the papers is invited, and should be sent to the Directorate for Science, Technology and Industry, OECD, 2 rue André Pascal, 75775 Paris Cedex 16, France.

The opinions expressed in these papers are the sole responsibility of the author(s) and do not necessarily reflect those of the OECD or of the governments of its Member countries.

http://www.oecd.org/sti/working-papers

Copyright OECD, 2002

Applications for permission to reproduce or translate all or part of this material should be made to: OECD Publications, 2 rue André-Pascal, 75775 Paris, Cedex 16, France. 
DSTI/DOC(2002)12

\title{
USE OF PLANT LEVEL MICRO-DATA FOR THE EVALUATION OF SME INNOVATION POLICY IN JAPAN ${ }^{1}$
}

\author{
Kazuyuki Motohashi ${ }^{2}$ \\ Institute of Innovation Research, Hitotsubashi University, Japan \\ and \\ Research Institute of Economy Trade and Industry (RIETI), Japan
}

\begin{abstract}
Japan's SME policies have reached a turning point. The traditional policy of "lifting up SMEs" has been changed into a more pro-competitive policy to foster entrepreneurship and innovation in SMEs. This paper evaluates this policy and the new innovation promotion schemes initiated by METI through an examination of plant-level micro data. Longitudinal micro-data from the Census of Manufacturing are linked to the list of firms participating in SME innovation policy schemes under the Law on Creative Activities in SMEs and the Law on Supporting Business Innovation in SMEs. The plant-level pattern of industrial dynamics suggests that both policies for new business start-ups and for innovation creation in existing firms are important. In addition, positive effects on sales growth are observed for firms that participate in the programme on Creative Activity Laws.
\end{abstract}

JEL classification: C35, L10, L50.

Keywords: Firm growth, SME innovation policy, programme evaluation, sample selection model.

1. A previous version of this paper was entitled "Use of Firm Demographic Data for SME Policy Evaluation", and was presented at the CAED01 conference in Aarhus, Denmark, 10-12 October 2001.

2. Associate Professor at Hitotsubashi University (motohashi@iir.hit-u.ac.jp) and Senior Manager of Quantitative Studies and Senior Fellow of RIETI. (motohashi-kazuyuki@rieti.go.jp). The views expressed in this paper are those of the author and do not necessarily reflect those of the affiliated organisations. 
DSTI/DOC(2002)12

\title{
UTILISATION DE MICRO-DONNÉES RECUEILLIES AU NIVEAU DE L'ENTREPRISE POUR ÉVALUER LA POLITIQUE D'INNOVATION DES PME JAPONAISES ${ }^{3}$
}

\author{
Kazuyuki Motohashi \\ Université de Hitotsubashi, Japon \\ et \\ Institut de recherche en économie, commerce et industrie (RIETI), Japon
}

\begin{abstract}
Résumé
Au Japon, les politiques concernant les PME ont évolué de manière décisive. La politique traditionnelle qui consistait à «donner un coup de pouce » à ces entreprises a été abandonnée en faveur d'une politique plus axée sur la concurrence afin d'y encourager l'esprit d'entreprise et l'innovation. Le présent document évalue cette politique ainsi que les nouveaux programmes de promotion de l'innovation lancés par le METI, en examinant des micro-données recueillies au niveau de l'entreprise. Les données longitudinales provenant du Recensement des industries manufacturières sont liées à la liste des entreprises participant au programme d'action en faveur de l'innovation dans les PME en vertu de la loi sur les activités créatives dans les PME et de la loi sur l'aide à l'innovation dans les PME. La simulation effectuée grâce au modèle de dynamique industrielle au niveau de l'entreprise conduit à penser que ces deux dispositions concernant la création de "jeunes pousses » et l'innovation dans les entreprises existantes - sont importantes. De surcroît, des effets positifs sur l'augmentation des ventes ont été observés dans les entreprises participant au programme inspiré de la loi sur les activités créatives.
\end{abstract}

Classification JEL : C35, L10, L50.

Mots clés: Croissance des entreprises, politique d'innovation dans les PME, évaluation de programme, modèle de sélection d'échantillons.

3. Intitulée «Use of Firm Demographic Data for SME Policy Evaluation», la version précédente de ce document a été présentée à la conférence CAED01 qui s'est tenue à Aarhus, au Danemark, du 10 au 12 octobre 2001. 


\section{TABLE OF CONTENTS}

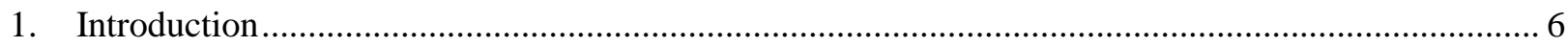

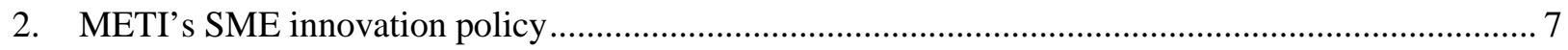

(1) Reform of METI's SME innovation policy ……................................................................. 7

(2) Law for promotion of creative business activities of SMEs ............................................... 7

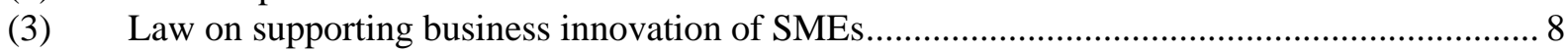

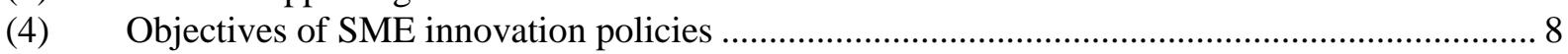

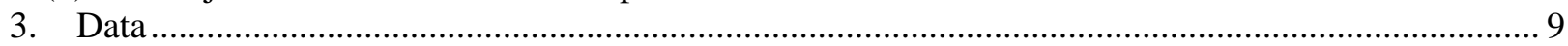

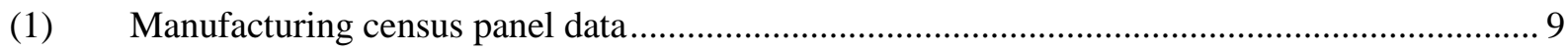

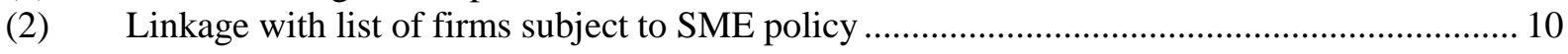

4. SMEs in a competitive environment and implications for innovation policy ................................. 10

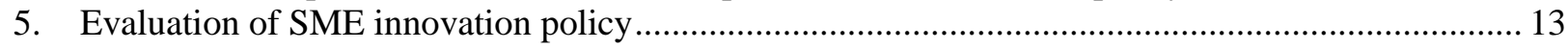

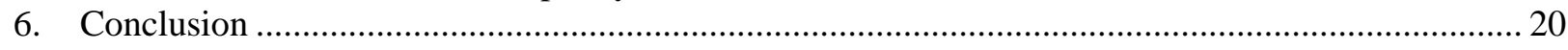

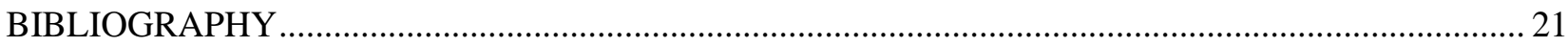




\section{Introduction}

SME policies in Japan have reached a turning point. During the 30 years since the end of the Second World War, they focused on reducing the gap in productivity and wages between SMEs and large corporations. Currently, they are undergoing a process of transformation towards a policy where SMEs are regarded as the source of entrepreneurship and innovation, and contributing to economic dynamism. Consequently, support should be aimed at individual high growth SMEs. Based on this fundamental idea, METI is undertaking a drastic reform of SME policy through various actions, including the amendment of the SME Basic Law in 1999.

As background to this policy change, analysis at the establishment or firm level of official statistics, such as the Census of Establishments and Enterprises and the Census of Manufacturing, provides important insights into the dynamics of firm demography and the heterogeneity of SMEs. The theory of a dual structure, which concentrates on the gap between large corporations and SMEs, is based on a comparison of the average large corporation and the average SME. However, it has become clear that, in fields such as $\mathrm{R} \& \mathrm{D}$, innovation, and business performance-related factors such as employment and productivity, SMEs show an amazingly large variation compared to large corporations (METI, 1999). Moreover, and considering that almost all large corporations began as SMEs, it is important not only to conduct analyses based on a static structure of firms, but also to consider dynamic firm-level trends reflecting expansion, contraction, entry and exit.

The heterogeneity of SMEs implies that there is no average SME, which was the target of traditional SME policies in the era of the dual structure. Instead, specific policies have been adopted for a variety of purposes, focusing on the SMEs that are to be targeted. These include, for example, policies to encourage SMEs in high-tech ventures; policies to promote business innovation in existing SMEs; and safety nets to protect SMEs from negative macro-economic shocks. To develop such policies, it is necessary to carry out an accurate analysis of economic activity using establishment-level or firm-level micro-data rather than aggregate data by industry or firm size.

Since the mid-1990s, METI has been actively compiling establishment and firm-level panel data. ${ }^{4}$ In developing a micro-data base, it is common for OECD countries to use administrative data, such as tax records, business registers and administrative records as a basis for linking statistical survey data. This is not the case in Japan. Instead, large-scale census surveys are conducted by visits to each establishment by enumerators, permitting examination of the entry and exit of the establishment, and the construction of data sets for establishment demography. Currently, METI is involved in a project to develop a comprehensive establishment and firm database. This involves linking firm-level data from the Basic Survey of Business Structure and Activity, and establishment data from various kinds of census statistics, such as the Census of Manufacturing, the Census of Commerce, and the Census of Selected Service Sectors.

This paper analyses establishment-level dynamics of the Japanese manufacturing sector by using longitudinal data sets from the Manufacturing Census. In addition, it presents analytical work on the evaluation of METI's policy measures to promote SME innovation. First, it provides a general description of METI's promotional measures for SME innovation, i.e. the Law for the Promotion of Creative Business Activities of Small and Medium Enterprises and the Law on Supporting Business Innovation of Small and Medium Enterprises. This is followed by discussion of establishment-level dynamics and its implications for SME innovation policy. Next, the paper discusses models and results of analytical work on SME innovation policy evaluation and considers the implications for future SME innovation policies.

4. Motohashi (2001) provides an overview of METI's activities in the development of longitudinal micro datasets. 


\section{METI's SME innovation policy}

\section{Reform of METI's SME innovation policy}

In response to the change in the basic SME policy direction mentioned above, METI totally reviewed its SME support policies in 1999. Several laws to promote SMEs exist to achieve various specific policy purposes, such as policies to vitalise regional clusters or to streamline distribution systems for SMEs. The most fundamental of these is the SME Modernization Promotion Law, a law introduced in 1963 which encourages the promotion of investment in SME facilities in order to abolish the dualistic structure between large corporations and SMEs in terms of productivity and wages.

The SME Modernization Promotion Law contributed to improvements in productivity, through the modernisation of SME equipment, at a time when the scale of profits was important for industrial productivity, and SMEs were handicapped due to their low level of capital intensity. However, as intangible investments such as investments in human resources and $\mathrm{R} \& \mathrm{D}$, rather than investments in tangible equipment, have become increasingly important, assistance schemes based on the SME Modernization Promotion Law have become obsolete and less able to meet the needs of SMEs. Also, this law is designed in such a way that sectors to be modernised must be specified, and all companies belonging to those sectors receive financial assistance. However, as the diversity in SMEs grows, the usefulness of supporting schemes by industry has decreased.

METI decided to abolish the SME Modernization Promotion Law in 1999, and worked to prepare a new scheme to support SME innovation. The Law on Supporting Business Innovation of Small and Medium Enterprises was established to support a wide range of innovation for SMEs, such as the development of new products and new production methods, rather than investment in equipment. At the time, the Law Concerning Promotion of the Advancement of SMEs into New Fields, which supports the transfer of SMEs involved in declining areas of business to other business fields, was combined with new innovation support schemes. Also, the streamlining and integration of the Law for the Promotion of Creative Business Activities of SMEs, which supports the opening of companies and technological development, was considered. However, since this law is effective until 2003 and many SMEs are still making use of the law's assistance policy schemes, it was decided to leave this particular law in place. Accordingly, the current METI schemes to promote SME innovation consist of the two pillars of the Law for the Promotion of Creative Business Activities of SMEs established in 1995 and the Law on Supporting Business Innovation of SMEs passed in 1999.

\section{Law for promotion of creative business activities of SMEs}

The schemes based on this law are composed of two parts: one to assist new business openings and the other to assist technological development. The former includes systems that recognise measures for taxation-related postponement of investment by individual investors in venture businesses, and direct financial support for venture businesses through local venture organisations.

For the latter, SMEs are required to submit proposals related to technological development projects. If it is judged that the project in question has important new features, and moreover if the project seems to have a high probability of successful completion in terms of capital and human resource allowances, subsidies, low-interest financing and taxation-related support can be granted. Although it is also possible for proposals to be put forward by groups of several SMEs, in almost all cases applications are from individual SMEs. As of June 2001, about 7400 proposals had been approved. 
The schemes based on this law ${ }^{5}$ begin with the submission of proposals related to broadly determined "innovation", including both product and process innovation, as is the case for the Law for Promotion of Creative Business Activities of SMEs. However, for the Law on Supporting Business Innovation of SMEs, it is also necessary to indicate a performance target in the proposal on innovation activities supported by this scheme ${ }^{6}$.

In addition, for each approved project, it is necessary to report to the government on the state of progress. The government also conducts follow-up inquiries, including examination of the progress made towards the performance target. Therefore, while the Law for Promotion of Creative Business Activities of SMEs requires a strict ex-ante examination process for project approval, the Law on Supporting Business Innovation of SMEs differs in that its focus is more on follow-up than on examination at the application stage. For this latter law also, a group of SMEs can submit a proposal, but in almost all cases the applications are made by individual SMEs. As of June 2001, about 1400 proposals had been approved.

\section{Objectives of SME innovation policies}

In order to evaluate the programmes of each of these two laws, it is important to clarify objectives and firms targeted by these policies. Both laws are schemes to promote SME innovation, which is the top priority of METI's SME policies, since new business openings and active new product development and business field transfers in SMEs become a source of strength for the dynamism of the economy as a whole. In fact, a large proportion of new employment created in the past was by high-growth SMEs, as can be observed in many OECD countries (OECD, 1996). At the same time, SMEs are often handicapped in certain aspects of the acquisition of capital and human resources. When SMEs start new operations, there are many managers who point to obstacles in the acquisition of capital and personnel (MITI, 2000). Also, detrimental effects of market failure that occur in financial and labour markets as a result of a lack of symmetry of information etc., are often considered to be more severe for SMEs. Policies to promote SME innovation can be justified in this way.

Both SME laws have the objective of supporting SME innovation, but the SMEs targeted by each law are slightly different. As mentioned above, a firm whose size is below a certain level is known as an SME. However, in reality SMEs are very diverse, and the dynamic changes involved, such as expansion and contraction of firm size, also need to be considered.

Since the Law for Promotion of Creative Business Activities of SMEs is basically a scheme to support high-tech ventures, technological development projects are expected to have a high degree of newness, and the purpose is mainly to support high-risk, high-return projects. For the Law on Supporting Business Innovation of SMEs, in contrast, the chief aim is to promote the revitalisation of existing companies through a broad range of innovations. When considering the promotion of SME innovation, the focus is often on companies that have advanced technology and grow rapidly. However, such corporations comprise an extremely small percentage of all SMEs, so it is important to carry out revitalisation of the other kinds of companies that comprise the vast majority of SMEs. The Law on Supporting Business

5. The Law for the Promotion of Creative Business Activities in SMEs is composed of a part dealing with innovation support and another dealing with an emergency safety net. The latter concerns business fields in which there has been an extreme deterioration of conditions as a result of external shocks, e.g. large changes in competitive conditions. The paper only describes the schemes dealing with innovation support.

6. The performance target can be either the growth rate of value added or that of labour productivity. 
Innovation of SMEs therefore has as its main goal the promotion of innovations in products and processes for as many SMEs as possible.

\section{Data}

\section{Manufacturing census panel data}

The longitudinal data set used for policy evaluation in this paper is based on plant-level survey data compiled by the Manufacturing Census. The Manufacturing Census used to be an annual survey of all establishments, but recently the complete census survey has been undertaken only in years that end in 0,3 , 5 or 8 , while in other years there is a supplementary survey of only establishments with four or more employees. The survey consists of Survey A for establishments with 30 or more employees, and the simpler Survey B, aimed at establishments with 29 or fewer employees. The total number of establishments covered is about 650000 , of which about 60000 are covered by Survey A. The Manufacturing Census survey is conducted by survey staff who have been appointed in each geographical district for on-site surveying, so that the opening of new establishments and the closing of existing ones are accurately reflected in the list of establishments in the survey.

Every year, the survey is conducted by using the identification number for each establishment, which is called the establishment code, so that the longitudinal data can be compiled based on this code. The data used in this paper are annual panel data from 1986 and 1999, and include a significant number of entries and exits of establishments. It should be noted that a complete census survey is not conducted every year; only establishments with four or more employees are surveyed in some years. Therefore, the identification code table for all establishments from 1986 to 1999 was compiled first, and each year's data for establishments with four or more employees were linked to this ID code table. ${ }^{7}$ The total number of establishments appearing in the table is 1234828 . The number of establishments with four or more employees was 437574 in 1988 and 373713 in 1998, and 236565 of them appear in datasets throughout the period from 1988 to $1998 .^{8}$

It should be noted that the establishment-level turnover of these datasets not only reflects entries and exits of establishments, but also includes changes in the number of establishments across the survey threshold. The share of establishments with 1-3 employees in the total number is $41.9 \%$, but this accounts for $5.4 \%$ in employment and $1.8 \%$ in value added in 1998. Therefore, it is assumed that biases associated with missing these establishments are small for the employment and productivity analysis provided later in this paper. In addition, it is often observed that the attrition rate of very small firms is very high, and such fragile SMEs are not good control samples to analyse the impact of SME innovation promotion policy.

The variables covered in this dataset are shipments, material inputs, number of employees, wages, the fourdigit Japanese Industrial Classification (JSIC) code, etc. Information on capital inputs such as investments and the book-value capital stock amount is available only for establishments with 10 or more employees.

7. Establishments with 1-3 employees are surveyed in complete census years, but individual plant data are not available in a computer-readable format. Therefore, data for " $4+$ establishments" are used for all years in this paper.

8. The number of 4+ establishments is measured in census years, such as 1988 and 1998, instead of 1986 and 1999 , since the survey is more reliable in census years than in other years. 
Real value added for each establishment in each year is calculated by using input and output deflators at the three-digit JISC level. ${ }^{9}$

\section{Linkage with list of firms subject to SME policy}

Analysis on the effectiveness of innovation policy was carried out by linking a list of the firms that are receiving policy assistance, such as subsidies or low-interest financing, with the manufacturing census longitudinal data mentioned above. Linkages have been made by aggregating establishment census data to the firm level by using firm identifiers first, and matching them by the firm's name and address, with the list of firms supported by the two laws on SME innovation promotion. As of June 2001, there are about 7400 companies that are subject to the Law for Promotion of Creative Business Activities of SMEs that began in 1995. Of these, about 2800 have manufacturing as their main business. The Law on Supporting Business Innovation of SMEs that began in 1999 covers about 1400 companies (of these, about 800 have manufacturing as their main business). We were able to make a linkage for 1360 companies (3 123 establishments) for the former law and 392 companies (1 004 establishments) for the latter law. Moreover, when a firm is subject to SME policies, innovation benefits such as new technology and new product development tend to appear in all the establishments owned by the firm in question. Therefore, the analysis in the following sections is conducted at the establishment level.

\section{SMEs in a competitive environment and implications for innovation policy}

METI is involved in various kinds of support schemes to promote innovation, taking the view that SMEs are a source for the creation of employment and economic dynamism. It is important to evaluate this hypothesis, which serves as a foundation for METI's SME innovation promotion policy, before programme evaluation of specific policy schemes is conducted. This section uses the manufacturing census longitudinal data to describe micro-level performance of SMEs and their role in shaping industrial dynamism in a competitive environment.

Some stylised facts on micro-level dynamics are commonly found in other countries. First, a common stylised fact is the smaller the size of the firm, the greater the speed of expansion of firm scale, in terms of number of employees (Caves, 1998). Even in countries such as the United States and France, where there has been a trend for large corporations to downsize, a move to expand employment in SMEs can be observed (Motohashi, 1998). At the same time, in contrast to the employment level in large corporations, where changes occur comparatively steadily over time, changes in employment in smaller companies tend to be dramatic, and frequently lead to businesses closing. Therefore, it is possible that an examination of the trends of surviving companies may produce an upward sampling bias on the growth rate. A second stylised fact is thus that the smaller the scale of the firm, the greater the variance in the speed of growth.

The Passive Learning Model (Jovanovic, 1982) can be used as a model to explain these stylised facts related to firm growth. This model is constructed under the assumption that each firm (owner) has its own level of ability, but at the time of establishing the firm, the firm (owner) does not have information on this ability. Information on managerial ability is passively learned in the course of conducting operations. Decisions on the expansion or contraction of the firm are made, based on the posterior of managerial ability, inferred by past information on the firm's performance. According to this model, the smaller the scale of the firm, the greater the variance in growth, and moreover, the greater the speed of growth of surviving companies (see Dunne, Roberts and Samuelson, 1988).

9. The deflator at the three-digit JSIC level (176 sectors for manufacturing) is compiled by using information from input-output tables. 
In contrast, there is another model in which the owner is aware of his/her own level of ability and the relevant market conditions, and there is active exploitation by the owner. In this case, management decisions take place as profitability parameters change stochastically over time (Ericson and Pakes, 1995). A major difference between this model and the passive learning model lies in whether or not the ability parameter changes over time, i.e. time invariant in the passive learning model, and time variant in the active exploitation model. An empirical test to distinguish between the two models is provided in Pakes and Ericson (1998). It has been shown that in the United States, companies involved in the distribution business follow the passive learning model, while those in manufacturing tend to follow a pattern closely linked to the active exploitation model.

The policy implications of these two models are quite different. That is, in the passive learning model, as a firm grows and gets older, the speed of growth in size decreases and becomes stable due to more precision on the inferred managerial ability. Therefore, dynamic economic changes occur only as a result of the exit of low-productivity firms from the market and firm and productivity growth in newly established firms. In this world, it is important to promote new firm openings and to remove obstacles to firms' exit. In contrast, the active exploitation model assumes that managers are facing competitive pressure from other firms, and actively exploiting any possibility to improve performance of their own firm. In this world, policies to nurture a competitive environment for innovation are important, and the revitalisation of existing SMEs can also be a policy target.

By examining industrial statistics panel data, the relationship between the entry and exit of establishments and firm scale and productivity can be observed. In Table 1, all establishments are classified into groups depending on whether or not the establishments in question survived in each year of the complete census, i.e. $1988(\mathrm{~T}=1), 1990(\mathrm{~T}=2), 1993(\mathrm{~T}=3), 1995(\mathrm{~T}=4)$ and $1998(\mathrm{~T}=5)$. For example, Group 123 denotes establishments that existed in 1988, 1990 and 1993, but not in 1995 and 1998. Hence, these establishments must have exited the market between 1993 and 1995. In another example, establishments that survived through all the years are depicted in the diagram as 12345.

Firstly, it is clear that those establishments that survived over all years are comparatively large and have a high level of labour productivity. Furthermore, establishments which opened between 1989 and 1990 and which survived until 1998 (Group 2345), and establishments which opened between 1996 and 1998 (Group 5) also have comparatively high productivity. On the other hand, establishments that opened between 1989 and 1990 but closed by 1997 (Groups 2, 23, and 234), were small in size and their productivity level was relatively low from the beginning. If we look at employment and productivity growth, and compare this with establishments that continue to exist over time, establishments that opened in 1989 or later have a relatively high growth rate. In particular, during the 1995-1998 period, when there was a dramatic decrease in the number of employees in the manufacturing industry, establishments that opened in 1996 or later showed a growth trend. Since there is also a growth trend in labour productivity for these establishments, there has been a rapid expansion in the scale of these establishments. 
Table 1. Productivity and employment by establishment type (entry, stay and exit)

\begin{tabular}{|c|c|c|c|c|c|c|c|c|c|c|c|}
\hline \multirow[t]{2}{*}{ Est type } & \multirow[t]{2}{*}{ \# of obs. } & VAE63 & VAE2 & VAE5 & VAE7 & VAE10 & JEMP63 & EMP2 & EMP5 & EMP7 & EMP10 \\
\hline & & 1988 & $\begin{array}{r}1990 \\
\end{array}$ & 1993 & \begin{tabular}{r|}
1995 \\
\end{tabular} & 1998 & \begin{tabular}{|r|}
1998 \\
\end{tabular} & 1990 & 1993 & \begin{tabular}{r|}
1995 \\
\end{tabular} & 1998 \\
\hline 11 & 88903 & 502 & 工 & & & & 14 & & & & . \\
\hline 12 & 42845 & 485 & 544 & . & . & & 13 & 12 & . & . & . \\
\hline 123 & 30387 & 484 & 553 & 526 & . & & 15 & 15 & 13 & & . \\
\hline 1234 & 46358 & 518 & 587 & 572 & 553 & & 17 & 17 & 16 & 14 & . \\
\hline 12345 & 236565 & 646 & 739 & 736 & 737 & 723 & 34 & 35 & 35 & 34 & 31 \\
\hline & 41624 & & 579 & . & . & & . & 15 & 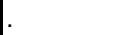 & . & . \\
\hline 23 & 10175 & & 546 & 530 & & & . & 12 & 11 & & . \\
\hline 234 & 13092 & & 573 & 584 & 571 & & . & 13 & 13 & 12 & . \\
\hline 2345 & 49494 & & 667 & 701 & 710 & 697 & . & 20 & 22 & 22 & 21 \\
\hline 3 & 37688 & & . & 639 & . & & . & . & 16 & & . \\
\hline 34 & 2928 & & . & 467 & 437 & & . & . & 7 & 6 & . \\
\hline 345 & 5952 & & . & 549 & 543 & 540 & . & . & 9 & 10 & 10 \\
\hline 4 & 45384 & & . & . & 698 & & . & & & 18 & \\
\hline 45 & 2791 & & . & . & 468 & 484 & . & . & . & 8 & 8 \\
\hline 5 & 83763 & & . & . & & 728 & & . & . & & 18 \\
\hline
\end{tabular}

\begin{tabular}{|c|c|c|c|c|c|c|c|c|c|}
\hline & & \begin{tabular}{|l} 
EMPG632 \\
$1988-90$
\end{tabular} & $\begin{array}{l}\text { EMPG25 } \\
1990-93\end{array}$ & $\begin{array}{l}\text { EMPG57 } \\
1993-95\end{array}$ & $\begin{array}{l}\text { EMPG710 } \\
1995-98\end{array}$ & $\begin{array}{l}\text { VAEG632 } \\
1988-90\end{array}$ & $\begin{array}{l}\text { VAEG25 } \\
1990-93\end{array}$ & $\begin{array}{l}\text { VAEG57 } \\
1993-95\end{array}$ & $\begin{array}{l}\text { VAEG710 } \\
\text { 1995-98 }\end{array}$ \\
\hline 1 & 88903 & & & & & & & & \\
\hline 12 & 42845 & $-1.55 \%$ & & & & $8.27 \%$ & & & \\
\hline 123 & 30387 & $-0.79 \%$ & $-3.54 \%$ & & & $8.65 \%$ & $-0.41 \%$ & & \\
\hline 1234 & 46358 & $-0.26 \%$ & $-2.17 \%$ & $-2.93 \%$ & & $9.08 \%$ & $0.55 \%$ & $1.69 \%$ & \\
\hline 12345 & 236565 & $1.04 \%$ & $-0.68 \%$ & $-0.60 \%$ & $-1.62 \%$ & $9.62 \%$ & $1.49 \%$ & $2.64 \%$ & $0.46 \%$ \\
\hline 2 & 41624 & & & & & & & & \\
\hline 23 & 10175 & & $-2.10 \%$ & & & & $2.55 \%$ & & \\
\hline 234 & 13092 & & $-0.70 \%$ & $-1.77 \%$ & & & $3.68 \%$ & $2.98 \%$ & \\
\hline 2345 & 49494 & & $1.00 \%$ & $0.66 \%$ & $-0.36 \%$ & & $4.73 \%$ & $4.53 \%$ & $0.90 \%$ \\
\hline 3 & 37688 & & & & & & & & \\
\hline 34 & 2928 & & & $0.11 \%$ & & & & $3.81 \%$ & \\
\hline 345 & 5952 & & & $2.24 \%$ & $0.59 \%$ & & & $4.70 \%$ & $1.04 \%$ \\
\hline 4 & 45384 & & & & & & & & \\
\hline 45 & 2791 & & & & $1.26 \%$ & & & & $1.62 \%$ \\
\hline 5 & 83763 & & & & & & & & \\
\hline
\end{tabular}

These observations suggest that Japan's manufacturing industry follows a pattern that can be explained by the Passive Learning Model, in which the firm scale is small for comparatively young establishments, with employment and labour productivity having a large variance. However, there is some evidence that there are dynamic trends in SMEs with a steady and relatively large scale as well. For establishments that survived over time, employment and labour productivity growth were examined by groupings based on whether or not changes occurred in the JSIC three-level industrial classifications between 1988 and 1993 or between 1993 and 1998. As can be seen from Table 2, establishments without a JSIC change tend to have a slightly large scale and higher productivity, but the difference is not all that large. On the other hand, looking at growth in labour productivity, those establishments with a JSIC change show a higher growth rate. Since the labour growth rate is almost the same as for establishments without a JSIC change, this implies that the growth in productivity was brought about by an expansion in value added. Thus, it is true that economic dynamism is brought about not only by establishment entry and exit, but also by innovations for creating new markets on the part of existing establishments. 
DSTI/DOC(2002)12

Table 2. Productivity and employment by JSIC change

\begin{tabular}{|c|c|c|c|c|c|c|c|c|c|c|c|}
\hline & \multirow[t]{2}{*}{ \# of obs. } & \multicolumn{5}{|c|}{ Labor productivity level } & \multicolumn{5}{|c|}{ Employment level } \\
\hline & & 1988 & \begin{tabular}{l|l|}
1990 & \\
\end{tabular} & 1993 & 1995 & 1998 & 1998 & 1990 & 1993 & 1995 & 1998 \\
\hline All & 236620 & 2682 & 758 & $\mid 719$ & 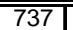 & 800 & \begin{tabular}{l|l}
34 \\
\end{tabular} & 35 & 35 & 34 & 31 \\
\hline JSIC no change & 170734 & 719 & 788 & 747 & 762 & 823 & 36 & 37 & 37 & 36 & 33 \\
\hline JSIC change 88-93 & 17871 & 616 & 715 & 685 & 704 & 796 & 32 & 33 & 31 & 30 & 29 \\
\hline JSIC change 93-98 & 10791 & 617 & 702 & 651 & 686 & 774 & 30 & 31 & 29 & 28 & 27 \\
\hline JSIC change 88-93-98 & 37224 & 559 & 652 & 619 & 645 & 704 & 26 & 27 & 27 & 26 & 23 \\
\hline
\end{tabular}

\begin{tabular}{|c|c|c|c|c|c|c|c|c|c|}
\hline & \multirow[t]{2}{*}{ \# of obs. } & \multicolumn{4}{|c|}{ Employment growth } & \multicolumn{4}{|c|}{ Labor productivity growth } \\
\hline & & 1988-90 & 1990-93 & 1993-95 & 1995-98 & $1988-90$ & $1990-93$ & 1993-95 & 1995-98 \\
\hline$\overline{\mathrm{All}}$ & 236620 & $1.04 \%$ & $-0.68 \%$ & $-0.60 \%$ & $-1.62 \%$ & 9.45\% & \begin{tabular}{c|c|}
$-0.09 \%$ \\
\end{tabular} & $0.47 \%$ & $3.16 \%$ \\
\hline JSIC no change & 170734 & $1.02 \%$ & $-0.48 \%$ & $-0.61 \%$ & $-1.67 \%$ & $8.36 \%$ & $-0.14 \%$ & $0.36 \%$ & $2.75 \%$ \\
\hline JSIC change 88-93 & 17871 & $1.89 \%$ & $-0.99 \%$ & $-0.17 \%$ & $-1.37 \%$ & $13.33 \%$ & $0.56 \%$ & $0.75 \%$ & $4.63 \%$ \\
\hline JSIC change 93-98 & 10791 & $1.20 \%$ & $-1.34 \%$ & $-0.70 \%$ & $-1.47 \%$ & $11.15 \%$ & $-0.68 \%$ & $0.88 \%$ & $4.60 \%$ \\
\hline JSIC change 88-93-98 & 37224 & $0.64 \%$ & $-1.34 \%$ & $-0.79 \%$ & $-1.55 \%$ & $12.23 \%$ & $-0.01 \%$ & $0.79 \%$ & $4.04 \%$ \\
\hline
\end{tabular}

As shown in the above observations, SMEs can be a potential driver of economic dynamism leading to the expansion of employment and growth in value added during a period of sluggish overall economic performance in Japan. At the same time, it is also true that SMEs are typically in an unstable position in changing economic and managerial conditions. Traditional SME policies are focused on reducing the handicaps of SMEs compared to large corporations in areas such as the lack of economic resources and difficulties in obtaining capital and personnel. However, it has become more important to formulate policies to develop SMEs as sources of growth. From this viewpoint, the concern is how to support SMEs with growth potential, and how to induce innovative activities for transforming potential growth into actual growth. In this case, the promotion of high-growth venture businesses is of course important, but it is no less important to encourage business innovation in existing corporations, in order to revitalise the whole economy.

\section{Evaluation of SME innovation policy}

The evaluation of METI's SME innovation policy in this section addresses two questions. The first is whether or not policy support offered under the two innovation promotion schemes has reached SMEs with the targeted characteristics, i.e. relatively new and high-tech firms for the Law for Promotion of Creative Business Activities of SMEs (Creative Activity Law: CAL) and relatively stable existing firms for the Law on Supporting Business Innovation of SMEs (Business Innovation Law: BIL). Since the selection process of both schemes is due to actions taken by participants, it is important to check whether firms have applied to the right scheme in line with policymakers' intentions. ${ }^{10}$ The second question is whether or not policy programmes have had an impact on a firm's business performance, such as growth in sales, employment and productivity. In this programme evaluation, it is important to check the marginal effect of programme participation, because participating firms might have performed well even without programme participation. It is impossible to conduct an experimental study in the social science field, but this kind of question can be addressed by using data sets with good control samples (Jarmin and Jensen, 1997), as is the case for this study. This performance evaluation study is conducted only for the Creative Activity Law, because the Business Innovation Law started in 1999, and no data on after-programme performance are available.

Summary statistics based on manufacturing census longitudinal data with SME innovation policy participant identifiers are provided in Table 3. It was found that for both schemes, participant firms are relatively large in employment size, and high in labour productivity, average wage and capital/employment ratio. In addition, participating firms show better business performance in the growth rates of sales,

10. It should be noted that the selection process by SMEs is not completely endogenous; applicants for support schemes often ask programme officers for advice on the scheme best fitting their needs. 
employment and labour productivity. It is important to keep in mind the timing of policy support to see whether this comes from original managerial ability or from programme participation. The scheme under the Creative Activity Law (CAL) started in 1995, and the start year of the project for each participant is distributed between 1995 and 2001, while the Business Innovation Law (BIL) only started in 1999. It is observed that participants showed better performance well before programme participation for both laws. Table 3 also shows information on the establishment age and changes in industrial classification at the three-digit JSIC level from 1988 to 1998. In this respect, CAL participants and BIL participants show different patterns: the share of younger establishments and JSIC change are greater than average for CAL participants, but lower than average for BIL participants.

Table 3. Summary statistics of policy evaluation data set

\begin{tabular}{|c|c|c|c|}
\hline & $\begin{array}{l}\text { Creative } \\
\text { activity }\end{array}$ & $\begin{array}{l}\text { Business } \\
\text { innovation }\end{array}$ & All \\
\hline Number of establishments & 3123 & 1004 & 375133 \\
\hline Employment (persons) & $\begin{array}{l}48.0 \\
39.5\end{array}$ & $\begin{array}{l}50.4 \\
42.5\end{array}$ & $\begin{array}{l}23.7 \\
20.1\end{array}$ \\
\hline $\begin{array}{ll}\text { Labor productivity (million } & \\
\text { yen per employee) } & 1988 \\
& 1999 \\
\end{array}$ & $\begin{array}{l}803.0 \\
901.0\end{array}$ & $\begin{array}{l}845.9 \\
963.2\end{array}$ & $\begin{array}{l}633.2 \\
700.0\end{array}$ \\
\hline $\begin{array}{l}\text { Average wage (million } \\
\text { yen per employee) }\end{array}$ & $\begin{array}{l}321.4 \\
390.9\end{array}$ & $\begin{array}{l}325.8 \\
386.3\end{array}$ & $\begin{array}{l}277.5 \\
338.8\end{array}$ \\
\hline $\begin{array}{ll}\text { Capital/employment ratio } & \\
\text { (million yen per } & 1988 \\
\text { employee) } & 1999\end{array}$ & $\begin{array}{l}321.7 \\
552.2\end{array}$ & $\begin{array}{l}384.6 \\
649.1\end{array}$ & $\begin{array}{l}296.9 \\
505.5\end{array}$ \\
\hline $\begin{array}{l}1988-90 \\
1990-93 \\
1993-96 \\
1996-99\end{array}$ & $\begin{array}{r}10.01 \% \\
-0.85 \% \\
4.02 \% \\
0.03 \%\end{array}$ & $\begin{array}{r}7.40 \% \\
-0.03 \% \\
3.30 \% \\
0.68 \%\end{array}$ & $\begin{array}{r}7.11 \% \\
-0.77 \% \\
1.35 \% \\
-2.68 \%\end{array}$ \\
\hline $\begin{array}{r}\text { Employment growth (annual) } \\
1988-90 \\
1990-93 \\
1993-96 \\
1996-99\end{array}$ & $\begin{array}{r}2.35 \% \\
0.12 \% \\
0.07 \% \\
-1.10 \%\end{array}$ & $\begin{array}{r}1.79 \% \\
0.76 \% \\
-0.01 \% \\
-0.69 \%\end{array}$ & $\begin{array}{l}1.01 \% \\
-0.42 \% \\
-0.49 \% \\
-1.61 \%\end{array}$ \\
\hline $\begin{array}{l}1988-90 \\
1990-93 \\
1993-96 \\
1996-99\end{array}$ & $\begin{array}{r}11.96 \% \\
1.08 \% \\
5.18 \% \\
0.28 \%\end{array}$ & $\begin{array}{r}8.57 \% \\
1.34 \% \\
3.93 \% \\
-0.04 \%\end{array}$ & $\begin{array}{r}9.35 \% \\
0.52 \% \\
3.34 \% \\
-0.98 \%\end{array}$ \\
\hline $\begin{array}{l}\text { Share of est. open after } 1996 \\
\text { Share of est. open after } 1991 \\
\text { Share of est. open before } 1988\end{array}$ & $\begin{array}{l}27.1 \% \\
13.0 \% \\
59.9 \%\end{array}$ & $\begin{array}{l}24.3 \% \\
11.7 \% \\
64.0 \%\end{array}$ & $\begin{array}{l}24.8 \% \\
12.9 \% \\
62.3 \%\end{array}$ \\
\hline $\begin{array}{l}\text { Share of est. JSIC change } \\
\text { Share of est. no JSIC change }\end{array}$ & $\begin{array}{l}32.5 \% \\
67.5 \%\end{array}$ & $\begin{array}{l}26.0 \% \\
74.0 \%\end{array}$ & $\begin{array}{l}27.9 \% \\
72.1 \%\end{array}$ \\
\hline
\end{tabular}

To control for industry and size effect on the distribution of business performance, probit analysis was undertaken for both CAL establishments and BIL establishments. As can be seen in Table 4, the labour productivity growth premiums before programme participation disappear for both laws after controlling for industry, size and other effects. In contrast, ex-ante premiums on sales growth rates do not disappear for either law, and ex-ante employment growth rates have a positive correlation with BIL participation. Accordingly, a firm intending to grow, instead of improving efficiency, is likely to apply for the innovation 
promotion schemes. Such a firm is presumed to have the managerial ability to expand its business, and to gain a suitable market share.

Table 4a. Probit analysis (creative activity establishment $\mathbf{= 1}$ )

(t-value in parentheses, statistical significance at $1 \%$ level for *, $5 \%$ level for $* *, 10 \%$ for $* * *$ )

\begin{tabular}{|c|c|c|c|c|c|}
\hline Sales growth, 93-96 & - & $\begin{array}{l}0.15^{\star} \\
(7.67)\end{array}$ & & & \\
\hline Value added growth, 93-96 & - & & $\begin{array}{c}0.03 \\
(0.89)\end{array}$ & & \\
\hline Employment growth, 93-96 & - & & & $\begin{array}{l}-0.10 \\
(1.00)\end{array}$ & \\
\hline Labor prod. growth, 93-96 & - & & & & $\begin{array}{c}0.04 \\
(1.74)\end{array}$ \\
\hline Firm created after 1994(+) & $\begin{array}{c}0.15^{*} \\
(72.20)\end{array}$ & $\begin{array}{l}-0.05 \\
(0.57)\end{array}$ & $\begin{array}{l}-0.06 \\
(0.72)\end{array}$ & $\begin{array}{l}-0.04 \\
(0.31)\end{array}$ & $\begin{array}{l}-0.06 \\
(0.71)\end{array}$ \\
\hline Firm created after $1989(+)$ & $\begin{array}{c}0.02 \\
(0.89) \\
\end{array}$ & $\begin{array}{c}0.02 \\
(1.03) \\
\end{array}$ & $\begin{array}{c}0.03 \\
(2.51) \\
\end{array}$ & $\begin{array}{l}0.03 \\
(2.42) \\
\end{array}$ & $\begin{array}{l}0.04 \\
(2.59) \\
\end{array}$ \\
\hline Single plant firm(++) & $\begin{array}{c}-0.23^{\star \star} \\
(189.75)\end{array}$ & $\begin{array}{l}-0.16^{\star *} \\
(58.75)\end{array}$ & $\begin{array}{l}-0.16^{\star *} \\
(59.06)\end{array}$ & $\begin{array}{l}-0.15^{\star *} \\
(58.26)\end{array}$ & $\begin{array}{l}-0.16^{\star \star} \\
(58.76)\end{array}$ \\
\hline Single plant + single HQ firm $(++)$ & $\begin{array}{c}-0.10 \\
(20.90)\end{array}$ & $\begin{array}{c}-0.07^{\star \star} \\
(5.83)\end{array}$ & $\begin{array}{l}-0.08 \\
(7.13)\end{array}$ & $\begin{array}{c}-0.07^{\star *} \\
(6.18)\end{array}$ & $\begin{array}{l}-0.08 \\
(7.10)\end{array}$ \\
\hline Industry dummy & Yes & Yes & Yes & Yes & Yes \\
\hline Size dummy & Yes & Yes & Yes & Yes & Yes \\
\hline$\overline{\mathrm{N}}$ & 375133 & 259508 & 268374 & 271242 & 2268374 \\
\hline $\log L$ & -16540.7 & -11361.6 & -11654.3 & -11781.1 & -11653.9 \\
\hline
\end{tabular}

Table 4b. Probit Analysis (Business Innovation Establishment $\mathbf{= 1}$ )

(t-value in parenthses, statistical significance at $1 \%$ level for ${ }^{*}, 5 \%$ level for ${ }^{* *}, 10 \%$ for ${ }^{* * *}$ )

\begin{tabular}{|c|c|c|c|c|c|}
\hline Sales growth, 96-99 & & $\begin{array}{c}0.20^{*} \\
(17.37)\end{array}$ & & & \\
\hline Value added growth, 96-99 & - & & $\begin{array}{c}0.06 \\
(1.90)\end{array}$ & & \\
\hline Employment growth, 96-99 & & & & $\begin{array}{c}0.49^{*} \\
(14.65)\end{array}$ & \\
\hline Labor prod. growth, 96-99 & - & & & & $\begin{array}{l}0.00 \\
(0.00)\end{array}$ \\
\hline Firm created after 1994(+) & $\begin{array}{l}0.08^{*} \\
(9.04)\end{array}$ & $\begin{array}{c}0.02 \\
(0.31)\end{array}$ & $\begin{array}{c}0.03 \\
(0.74)\end{array}$ & $\begin{array}{c}0.03 \\
(0.77)\end{array}$ & $\begin{array}{c}0.03 \\
(0.95)\end{array}$ \\
\hline Firm created after 1989(+) & $\begin{array}{l}-0.03 \\
(0.60)\end{array}$ & $\begin{array}{l}-0.04 \\
(1.18)\end{array}$ & $\begin{array}{l}-0.04 \\
(1.26)\end{array}$ & $\begin{array}{l}-0.04 \\
(1.20)\end{array}$ & $\begin{array}{l}-0.04 \\
(1.20)\end{array}$ \\
\hline Single plant firm(++) & $\begin{array}{c}-0.31^{*} \\
(146.64)\end{array}$ & $\begin{array}{l}-0.25^{\star} \\
(69.63)\end{array}$ & $\begin{array}{c}-0.27^{*} \\
(87.73)\end{array}$ & $\begin{array}{c}-0.27^{\star} \\
(89.56)\end{array}$ & $\begin{array}{c}-0.27^{\star} \\
(87.94)\end{array}$ \\
\hline Single plant + single $\mathrm{HQ}$ firm $(++)$ & $\begin{array}{c}-0.12^{*} \\
(13.52)\end{array}$ & $\begin{array}{c}-0.08^{\star \star} \\
(4.63)\end{array}$ & $\begin{array}{l}-0.11^{*} \\
(8.38)\end{array}$ & $\begin{array}{l}-0.11^{*} \\
(7.69) \\
\end{array}$ & $\begin{array}{l}-0.11^{*} \\
(8.41) \\
\end{array}$ \\
\hline Industry dummy & Yes & Yes & Yes & Yes & Yes \\
\hline Size dummy & Yes & Yes & Yes & Yes & Yes \\
\hline$\overline{\mathrm{N}}$ & 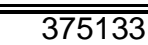 & 276711 & 285621 & 289715 & 285621 \\
\hline LogL & -6362.53 & -4951.86 & -5119.97 & -5230.55 & -5120.77 \\
\hline
\end{tabular}

It should be noted that positive and statistically significant coefficients for dummy variables for firms created after 1994 can be found not only for CAL participants, but also for BIL participants. Therefore, the 
smaller share of these firms in the BIL participants in Table 3 is biased, presumably due to the size characteristics of BIL - large establishments having a larger share in this programme. The Business Innovation Law is designed to stimulate product or process innovation for relatively stable existing SMEs, in contrast to the Creative Activity Law, which promotes high-tech ventures. However, it was found that BIL participants and CAL participants have similar characteristics, i.e. they are relatively new, large in size and are growing faster than the average firm. A first examination of the manufacturing census longitudinal data suggests an overlapping of policy targets by the two laws.

The performance evaluation study was conducted for the Creative Activity Law. The scheme under the Creative Activity Law started in 1995, and each participating firm is conducting projects on R\&D, product development, etc., according to the approved plan which lasts from one to five years. The distribution of the timing of the project is presented in Table 5. Out of the 3123 establishments in this dataset, about 500 establishments started the project each year, and 855 establishments were still active in 2001. Since the project covers the whole process from product development to the marketing of new products, most participants finished the development stage in the first few years of the project. Therefore, in the following analysis, post-project performance evaluation is provided for CAL participants that started the project before 1997.

Table 5. Number of CAL participating establishments

\begin{tabular}{l|ccccccc}
\hline & 1995 & 1996 & 1997 & 1998 & 1999 & 2000 & 2001 \\
\hline \hline \# of est. started & 220 & 729 & 570 & 511 & 597 & 426 & 70 \\
\# of est. active & 220 & 916 & 1264 & 1329 & 1403 & 1303 & 855 \\
\# of est. finished $^{1}$ & 0 & 33 & 222 & 446 & 523 & 526 & - \\
\hline
\end{tabular}

1. Establishments finished in 2001 are not tracked in the dataset.

OLS estimates of the effect of CAL participation on the sales growth rate from 1996 to 1999 are presented in Table 6. The value of sales is used for the business performance indicator, since it is relevant in evaluating the short-term effects of the programme, as compared to the productivity, which can be achieved over a relatively long term. In addition, by using the growth rate, time-invariant fixed effects, such as managerial ability, can be controlled. ${ }^{11}$ Compared to non-participants, establishments participating in CAL achieved about $1.3 \%$ more sales, after controlling for employment growth rates and other plant characteristics such as industry and size class. When all participants are split up by the timing of the project, starting before 1997 or after 1998, the group before 1997 shows $2.5 \%$ more sales growth, while groups after 1998 show no difference compared to non-participants. The same regression was conducted for each size class in 1995. Positive and significant coefficients can be found for establishment with more than 10 employees, but not for firms with 10 or fewer employees.

As is shown in Table 4, CAL participants show better performance in sales growth before participation. In addition, there is also an exogenous selection process by the government for approval of CAL projects. Therefore, in order to derive the pure effect of programme participation, we need to control for these selection biases. In this paper, Heckman's two-step procedure ${ }^{12}$ is used to derive consistent estimates on the effect of CAL participation.

11. Using the growth rate as a dependent variable gives fixed effect estimators in panel data analysis. When there are measurement errors in independent variables, taking three-year differences gives a better estimate compared to using shorter differences, such as the first difference model (Griliches and Hausman, 1986).

12. Heckman's two-step method is described in most standard econometrics textbooks. The econometric technique used in this paper is based on Maddala (1983). 
Table 6. OLS estimate: impact of Creative Activity Law

(Dependent variable $=$ sales growth, 1996-99)

(t-value in parentheses, statistical significance at $1 \%$ level for ${ }^{*}, 5 \%$ level for ${ }^{* *}, 10 \%$ for ${ }^{* * *}$

\begin{tabular}{l|c|c|c|c|c}
\hline & \multicolumn{2}{|c|}{} & & $\begin{array}{c}10<\text { EMP } \\
\text { EMP }=<50\end{array}$ & EMP $>50$ \\
\hline \hline Creative activity est. & \multicolumn{2}{|c|}{ All establishments } & EMP $=<10$ & - & - \\
& $0.013^{*}$ & - & - & - & \\
\hline Creative activity est. & $(4.58)$ & & & & $0.029^{*}$ \\
(started project before 1997) & - & $0.025^{*}$ & 0.007 & $0.030^{*}$ & $(4.21)$ \\
\hline Creative activity est. & - & 0.002 & 0.006 & 0.001 & -0.003 \\
(started project after 1998) & & $(0.55)$ & $(0.74)$ & $(0.20)$ & $(0.04)$ \\
\hline Employment growth, 96-99 & $0.646^{*}$ & $0.646^{*}$ & $0.608^{*}$ & $0.674^{*}$ & $0.698^{*}$ \\
& $(208.60)$ & $(208.61)$ & $(132.47)$ & $(142.13)$ & $(79.88)$ \\
\hline Firm created after 1994(+) & $0.036^{*}$ & $0.036^{*}$ & $0.032^{*}$ & $0.042^{*}$ & $0.042^{*}$ \\
& $(46.87)$ & $(46.87)$ & $(30.35)$ & $(32.50)$ & $(16.72)$ \\
\hline Firm created after 1989(+) & $0.011^{*}$ & $0.011^{*}$ & $0.010^{*}$ & $0.011^{*}$ & $0.014^{*}$ \\
& $(13.75)$ & $(13.76)$ & $(9.26)$ & $(8.52)$ & $(5.95)$ \\
\hline Single plant firm(++) & $-0.006^{*}$ & $-0.006^{*}$ & $-0.010^{*}$ & $-0.006^{*}$ & 0.000 \\
& $(7.33)$ & $(7.32)$ & $(6.40)$ & $(5.83)$ & $(0.43)$ \\
\hline Single plant + single HQ firm(++) & $-0.005^{*}$ & $-0.005^{*}$ & $-0.008^{*}$ & $-0.006^{*}$ & 0.000 \\
& $(4.52)$ & $(4.52)$ & $(4.24)$ & $(3.75)$ & $(0.18)$ \\
\hline Industry dummy & yes & yes & yes & yes & yes \\
\hline Size dummy & yes & yes & - & - & - \\
\hline \hline N & 289715 & 289715 & 229204 & 116759 & 29170 \\
\hline R-square & 0.142 & 0.143 & 0.115 & 0.167 & 0.199 \\
\hline
\end{tabular}

Note: $\quad+$ : As compared to firm created before 1988.

$\mathrm{EMP}=$ employment.

The first model is based on the assumption that coefficients for control variables are identical for participants and non-participants.

$$
\begin{gathered}
y_{i}=\beta_{i} X_{i}+\gamma C A L+u_{i} \\
p_{i}^{*}=\delta_{i} Z_{i}+\varepsilon_{i}, \mathrm{CAL}=1 \text { if } p_{i}^{*}>0 ; \text { otherwise } \mathrm{CAL}=0
\end{gathered}
$$

The effect of CAL participation is evaluated by the coefficient $\gamma$ after controlling for $\mathrm{X}$ in equation (1). The participation of CAL is determined by equation (2), but we can observe only CAL (participation or no participation), and not $\mathrm{p}^{*}$. If the error terms in the two equations are independent of each other, the OLS estimation of the first equation gives us a consistent estimate of $\gamma$, but this may not be the case. By assuming that the error terms of both equations are jointly normally distributed with the covariance matrix in (3), the expected value of $u_{i}$ is determined by (4) or (5), depending on CAL $=1$ or 0 .

$$
\begin{gathered}
\operatorname{Cov}\left(u_{i}, \varepsilon_{i}\right)=\left[\begin{array}{cc}
\sigma_{u} & \sigma_{u e} \\
\sigma_{u e} & 1
\end{array}\right] \\
E\left(u_{i} / C A L=1\right)=E\left(u_{i} / \varepsilon_{i}>-\delta_{i} Z_{i}\right)=\sigma_{u e} \frac{\phi\left(\delta_{i} Z_{i}\right)}{\Phi\left(\delta_{i} Z_{i}\right)}
\end{gathered}
$$




$$
E\left(u_{i} / C A L=0\right)=E\left(u_{i} / \varepsilon_{i}<-\delta_{i} Z_{i}\right)=-\sigma_{u e} \frac{\phi\left(\delta_{i} Z_{i}\right)}{1-\Phi\left(\delta_{i} Z_{i}\right)}
$$

In this situation, Heckman suggested computing $\delta_{i} Z_{i}$ by probit with equation (2) in the first step, and calculating (4) or (5) for each observation, which is used for the OLS estimate of equation (1) in the second step. Table 7 provides the results of this estimation procedure. ${ }^{13}$ The table compares CAL participants who started the project before 1997 to non-participants. The second step regression is conducted with or without size dummies. The statistically significant coefficient CAL in the second step is found for the regression without size dummies, while it is not found in the regression with size dummies. This result implies that the CAL effect on sales growth is uncertain at this stage. Alternatively, the assumption of similar coefficients for the control variables for participants and non-participants is too strong.

Table 7. OLS and 2 step estimate: impact of Creative Activity Law

(Dependent variable $=$ sales growth, 1996-99)

(t-value in parenthses)

(Statistical significance at $1 \%$ level for ${ }^{*}, 5 \%$ level for ${ }^{* *}, 10 \%$ for ${ }^{* * *}$ )

\begin{tabular}{l|c|c|c}
\hline & $\begin{array}{c}\text { First step } \\
\text { (probit) }\end{array}$ & $\begin{array}{c}\text { Second } \\
\text { step (1) }\end{array}$ & $\begin{array}{c}\text { second } \\
\text { step (2) }\end{array}$ \\
\hline \hline Creative activity est. & - & 0.041 & $0.068^{*}$ \\
(started project before 1997) & & $(0.94)$ & $(4.09)$ \\
\hline Inverse Mills ratio & - & -0.023 & $-0.039^{*}$ \\
& & $(0.61)$ & $(4.78)$ \\
\hline Employment growth, 93-96 & 0.085 & - & - \\
& $(0.30)$ & & \\
\hline Employment growth, 96-99 & - & $0.602^{*}$ & $0.600^{*}$ \\
& - & $(22.80)$ & $(22.78)$ \\
\hline Firm created after 1994(+) & - & 0.014 & 0.012 \\
& - & $(0.80)$ & $(0.69)$ \\
\hline Firm created after 1989(+) & -0.132 & $0.020^{*}$ & $0.020^{*}$ \\
& $(0.51)$ & $(3.44)$ & $(3.44)$ \\
\hline Single plant firm(++) & $-0.236^{*}$ & -0.005 & -0.002 \\
& $(11.40)$ & $(0.58)$ & $(0.36)$ \\
\hline Single plant + single HQ firm(++) & 0.075 & 0.002 & 0.003 \\
& $(0.91)$ & $(0.18)$ & $(0.40)$ \\
\hline Industry dummy & yes & yes & yes \\
\hline Size dummy & yes & yes & no \\
\hline \hline N & 3787 & 3502 & 3502 \\
\hline LogL & -2029 & - & - \\
\hline R-square & - & 0.138 & 0.137 \\
\hline
\end{tabular}

Note: $\quad+$ : As compared to firm created before 1988 .

++ : As compared to multiple plant firm.

In the second model, the assumption of identical coefficients of control variables is relaxed, as follows:

$$
\begin{gathered}
y_{1 i}=\beta_{1 i} X_{i}+u_{1 i}(\text { for participants; } \mathrm{CAL}=1) \\
y_{0 i}=\beta_{0 i} X_{i}+u_{0 i}(\text { for non participants; } \mathrm{CAL}=0)
\end{gathered}
$$

13. Due to the prohibitively large size of the original dataset, the empirical analysis is based on random sampling data with 5000 observations for a non-participating controlling sample. 


$$
p_{i}^{*}=\delta_{i} Z_{i}+\varepsilon_{i}, \mathrm{CAL}=1 \text { iff } p_{i}^{*}>0 ; \text { otherwise } \mathrm{CAL}=0
$$

and we assume that $u_{0 i}, u_{1 i}$ and $\varepsilon$ are jointly normally distributed with the covariance matrix in equation (9).

$$
\operatorname{Cov}\left(u_{0 i}, u_{1 i}, \varepsilon_{i}\right)=\left[\begin{array}{ccc}
\sigma_{0} & \sigma_{01} & \sigma_{0 e} \\
\sigma_{01} & \sigma_{1} & \sigma_{1 e} \\
\sigma_{0 e} & \sigma_{1 e} & 1
\end{array}\right]
$$

The methodology of the estimation is similar to that of the first model, i.e. estimating $\delta_{i} Z_{i}$ with equation (8) by probit in the first step, and calculating the inverse Mill's ratio, ${ }^{14}$ then conducting OLS estimation of (6) and (7) separately with the estimated inverse Mill's ratio. In this model, it is possible to calculate the expected gross benefit for CAL establishments of programme participation, i.e. to what extent sales growth rate goes up compared to the case where the establishment had not participated in CAL programme, by the following equation:

$$
E\left(y_{1 i} / C A L=1\right)-E\left(y_{0 i} / C A L=1\right)=X_{i}\left(\beta_{1}-\beta_{2}\right)+\left(\sigma_{1 e}-\sigma_{2 e}\right) \frac{\phi\left(\delta_{i} Z_{i}\right)}{\Phi\left(\delta_{i} Z_{i}\right)}(10)
$$

Figure 1 gives the plant distribution of the value in equation (10) for participants. More than $80 \%$ of plants show positive values with the peaks being in the category from 5\% to $10 \%$ higher growth rates. Therefore, it is possible to say that CAL participation has had positive impacts on sales growth, even after controlling for sample selection.

Heckman's two step procedure is a popular approach for programme evaluation analysis by data with possible selection bias, but it is based on strong assumptions on the normality in the distribution of error terms. There are recent studies showing that the parameter estimates are very sensitive to the distributional assumptions. In addition, when most of the independent variables for the first step and the second step are overlapping, as is the case for this study, regression results may give inconsistent estimates due to identification problems. In this sense, the results presented here should be read with great care, and in future research, further sensitivity analysis will be conducted by using different kinds of model specifications, including semi-parametric and non-parametric approaches proposed by Heckman (1990).

14. $\frac{\phi\left(\delta_{i} Z_{i}\right)}{\Phi\left(\delta_{i} Z_{i}\right)}$ for participants and $-\frac{\phi\left(\delta_{i} Z_{i}\right)}{1-\Phi\left(\delta_{i} Z_{i}\right)}$ for non-participants. 
Figure 1. Sales growth effect of Creative Activity Law

(Annual sales growth 1996-99, $\mathrm{N}=1519$, Mean $=+4.12 \%$ )

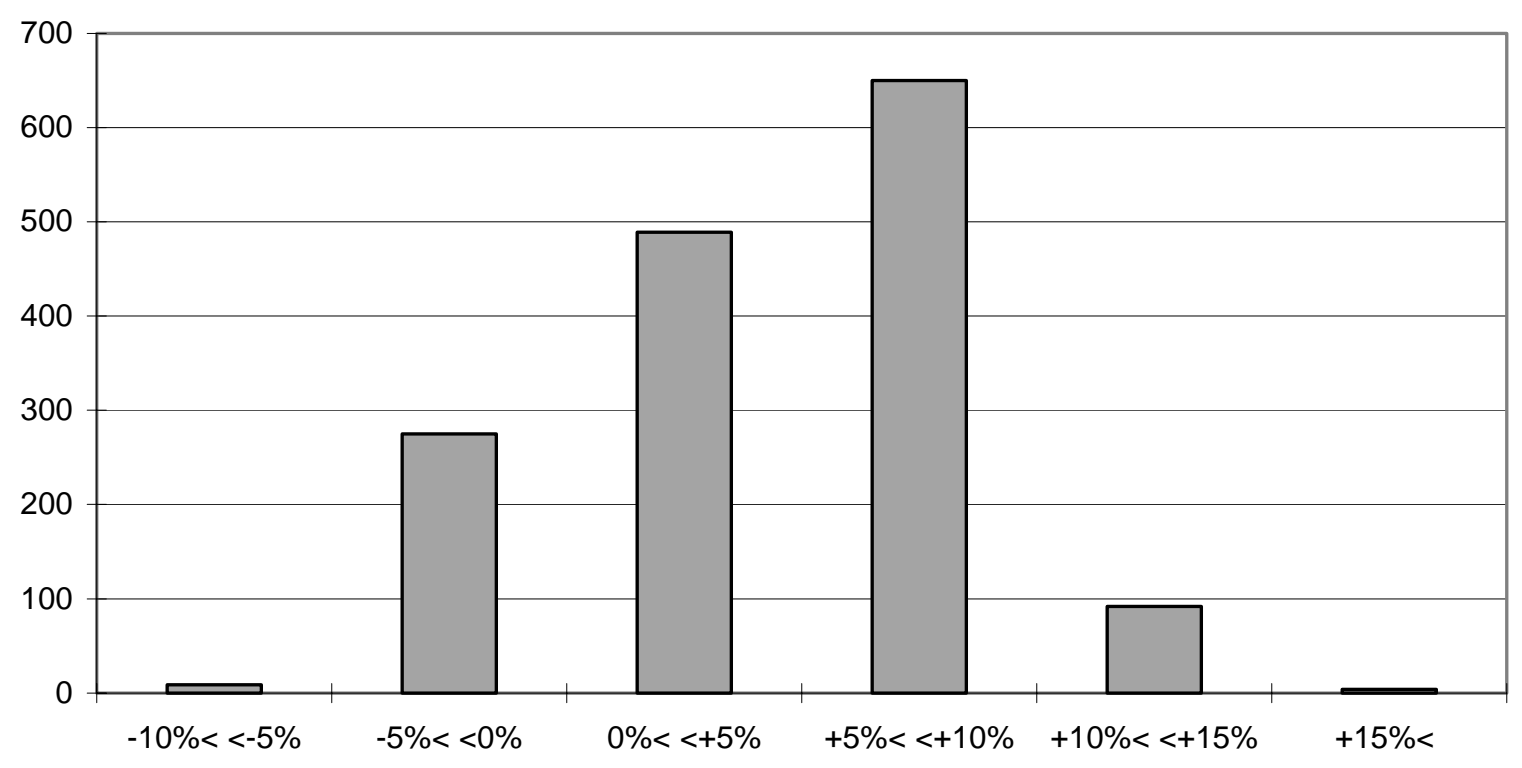

\section{Conclusion}

This paper used the manufacturing census longitudinal dataset to analyse SME innovation policy. METI's SME policy is in a process of transformation, which takes into account the greater growth potential of SMEs and treats them as a source of industrial dynamism for the Japanese economy. Establishment-level micro-data confirm that small and young plants have a greater potential for growth, but it is also shown that the volatility of growth rates is high for small establishments. In this sense, the focus of SME policy should be on supporting SMEs, so that they are able to realise their growth potential.

Analytical work on the evaluation of specific policy schemes, namely, the Law for Promotion of Creative Business Activities of SMEs and the Law on Supporting Business Innovation of SMEs is also provided. Participants in these two schemes show higher sales growth rates before programme participation, which implies that policy support seems to be provided for SMEs with a greater potential for further growth. However, it is also observed that similar kinds of firms are applying to these two schemes, and that these two supporting schemes could overlap. Although a more detailed study on the characteristics of participating firms is needed, this information should be taken into account for the future reform of METI's SME innovation policy. Performance evaluation of the Creative Activity Law was also conducted. In general, the policy scheme under the Creative Activity Law works well. However, further analysis based on more detailed data and semi- or non-parametric estimation methodologies to control for selectivity bias is needed to provide clearer views on the effects of the innovation policy and to provide more specific recommendations for improvement of the existing policy scheme. 


\section{BIBLIOGRAPHY}

Baily, Campbell and Hulten (1992), “The Distribution of Productivity in Manufacturing Plants", Brookings Papers on Economic Activities: Microeconomics, 1992.

Caves, R.E. (1998), "Industrial Organization and New Findings on the Turnover and Mobility of Firms", Journal of Economic Literature, Vol. XXXI, pp. 1947-1982.

Dunne, T., M. Roberts and L. Samuelson (1988), "Patterns of Firm Entry and Exit in US Manufacturing Industry”, Rand Journal of Economics, Vol. 19 (4), pp. 495-515.

Ericson, R. and A. Pakes (1995), "Markov-Perfect Industry Dynamics: Framework for Empirical Works", Review of Economic Studies, 62, pp. 53-82.

Griliches, Z, and J. Hausman (1986), "Errors in Variables in Panel Data", Journal of Econometrics, Vol .31, pp. 93-118.

Heckman, J. (1990), "Varieties in Selection Bias", American Economic Review, May 1990, pp. 313-318.

Jarmin, R. (1996), "Measuring the Impact of Manufacturing Extension Partnership", a paper presented for the International Conference on Comparative Analysis of Enterprise Data, June 1996, Helsinki.

Jarmin, R. and B. Jensen (1997), "Evaluating Government Technology Programmes: The Case of Manufacturing Extension", Chapter 14, OECD Proceedings: Policy Evaluation in Innovation and Technology: Toward Best Practices, OECD Paris.

Jovanovic, B. (1982), "Selection and the Evolution of the Industry", Econometrica, 50, pp. 649-670.

Maddala (1983), Limited Dependent and Qualitative Variables in Econometrics, Econometrics Society Monographs, Cambridge University Press.

MITI (1999), White Paper on Small and Medium Enterprises, Tokyo, Japan.

MITI (2000), White Paper on Small and Medium Enterprises, Tokyo, Japan.

Motohashi, K. (1998), "Technology, Productivity and Employment: Insights from Firm Level MicroDatasets in France, Japan and the United States", mimeo, July.

Motohashi, K. (2001), Development of Longitudinal Micro-Datasets and Policy Analysis for Japanese Industrial Sectors, REITI, Tokyo, Japan.

OECD (1996), Technology, Productivity and Job Creation, Vol. 2: Analytical Report, OECD, Paris.

Pakes, A. and R. Ericson (1998), "Empirical Implications of Alternative Models of Firm Dynamics", Journal of Economic Theory 79, pp.1-45. 